\title{
Perbedaan Kemampuan Bersosialisasi dan Kematangan Emosional Anak PAUD dan Non PAUD
}

\section{Dian Afriyanto", Siti Arifah ${ }^{2 *}$}

${ }^{1}$ Program Studi Ilmu Keperawatan Universitas Muhammadiyah Surakarta, Kartasura, 57162, Jawa Tengah, Indonesia.

${ }^{2}$ Departemen Keperawatan Anak, Program Studi Ilmu Keperawatan Universitas Muhammadiyah Surakarta, Kartasura, 57162, Jawa Tengah, Indonesia.

*Korespondensi: are_riefah@yahoo.com

\begin{abstract}
Abstrak: Perkembangan sosial merupakan suatu proses belajar untuk menyesuaikan diri terhadap moral, tradisi, norma dan saling berkomunikasi serta bekerja sama guna mencapai kematangan dalam hubungan sosial. Pendidikan anak usia dini (PAUD) merupakan salah satu upaya meningkatkan perkembangan anak agar tidak terhambat. Penelitian ini bertujuan untuk mengetahui adakah perbedaan kemampuan bersosialisasi dan kematangan emosi pada anak pra sekolah dengan PAUD dan tanpa PAUD. Penelitian ini merupakan penelitian kuantitatif dengan deskriptif komparatif. Populasi penelitian adalah anak pra sekolah yang berjumlah 91 anak, sedangkan sampel penelitian sebanyak 91 anak prasekolah dengan teknik total sampling. Hasil penelitian menunjukkan analisis perbedaan kemampuan bersosialisasi anak prasekolah dengan Paud dan Non Paud diperoleh nilai signifikansi ( $p$-value) 0,014 sehingga $\mathrm{H}_{0}$ ditolak dan perbedaan kematangan emosional anak prasekolah dengan Paud dan Non Paud diperoleh nilai signifikansi ( $p$-value) 0,000 sehingga $\mathrm{H}_{0}$ ditolak. Terdapat perbedaan kemampuan bersosialisasi pada anak prasekolah dengan PAUD dan tanpa PAUD dan terdapat perbedaan kematangan emosional pada anak prasekolah dengan PAUD dan tanpa PAUD.
\end{abstract}

Kata kunci: Anak Prasekolah, PAUD, Non PAUD, Kemampuan Bersosialisasi, Kematangan Emosional

Abstract: Social development is a process of learning to adjust to the morals, traditions, norms and communicate with each other and work together to reach maturity in social relations. Early childhood education (PAUD) is one way to improve a child's development from being obstructed. This study aims to know is there any difference in social skills and emotional maturity in pre-school children with early childhood and without early childhood. This research is a quantitative study with descriptive comparative. The study population was pre-school children totaling 91 children, while the samples are 91 preschoolers with total sampling technique. The results showed the analysis of differences in social skills of preschool children with early childhood and Non early childhood significance value ( $p$-value) 0,014 so Ho rejected and the difference in emotional maturity of preschool children with early childhood and Non early childhood significance value (p-value) 0,000 so Ho rejected. There are any differences in social skills in preschool children with early childhood and non early childhood and there are any differences in emotional maturity in preschool children with early childhood and non early childhood.

Keywords: Preschool Children, Early childhod, Non early childhood, Socializing Ability, Emotional Maturity 


\section{PENDAHULUAN}

Masa kanak-kanak merupakan masa paling awal dalam rentang kehidupan yang akan menentukan perkembangan anak pada tahap berikutnya (Hurlock, 2006). Salah satu masa kanak-kanak adalah usia prasekolah yaitu anak yang berusia antara 3-6 tahun (Padmonodewo, 2008). Perkembangan anak prasekolah dipusatkan untuk menjadi manusia sosial, belajar bergaul dengan orang lain. Perkembangan sosial merupakan suatu proses belajar untuk menyesuaikan diri terhadap moral, tradisi, norma dan saling berkomunikasi serta bekerja sama guna mencapai kematangan dalam hubungan sosial (Yusuf, 2011).

Langeveld dalam Riyanto (2004), mengemukakan kemampuan-kemampuan yang hendaknya dicapai anak prasekolah (3-6 tahun) antara lain, berbahasa lisan, berbicara dan bercerita, mengenal pola kehidupan sosial (aku, keluarga dan sekolah), mengerti dan menguasai ketrampilan untuk kepentingan kebutuhan sehari-hari, mulai mengenal dirinya sendiri dan keinginan serta kehendaknya, mulai berkhayal, dan belum dapat membedakan secara tegas antara kenyataan dan imajinasi belaka.

Usia prasekolah memberi kesempatan luas kepada anak untuk mengembangkan keterampilan sosialnya. Di usia inilah anak mulai melihat dunia lain di luar dunia rumah bersama ayah dan ibu. Kemampuan bersosialisasi harus terus diasah, mengingat seberapa jauh anak bisa meraih kesuksesannya amat ditentukan oleh banyaknya relasi yang sudah dijalin (Isye, 2006). Hal tersebut menunjukkan bahwa perkembangan sosialisasi pada anak usia prasekolah terpenting dipengaruhi oleh faktor keluarga yang merupakan agen sosialisasi dan lingkungan dimana anak itu tumbuh dan berkembang. Hubungan dengan orang tua atau pengasuhnya merupakan dasar bagi perkembangan emosional dan sosial anak.

Hasil penting yang harus dimiliki seorang anak ketika akan memasuki usia sekolah (anak prasekolah) adalah kemampuan sosialisasinya, tidak saja meliputi kecerdasan dan keterampilan motorik tetapi juga hal lain seperti dapat menerima tokoh diluar orang tuanya, kesadaran akan tugas, patuh pada peraturan, dan dapat mengendalikan emosi-emosinya (Suharsono dkk, 2009). Kemampuan sosialisasi yang harus dimiliki anak prasekolah, antara lain berteman, kerja sama, bertengkar, bersaing dan melawan (Setiawan, 2010).

Anak prasekolah yang tidak memiliki dasar kemampuan sosialisasi pada usia 6 tahun cenderung akan bermasalah dalam sosialisasi ketika dewasa (Ladd dalam Komariah, 2012). Anak yang kemampuan sosialisasinya rendah sering mengalami kemunduran prestasi akademik, banyak kasus tidak naik kelas, kurang aktif dalam pergaulan dengan teman dan kurang mampu untuk menjalin hubungan yang baik dengan orang lain. Sehingga dapat diartikan bahwa anak yang kemampuan sosialisasinya kurang, tidak mampu bereaksi sesuai harapan lingkungan sosial dan mengalami hambatan untuk menyesuaikan diri dengan lingkungan (Ibung, 2009).

Anak dengan kemampuan sosial yang baik, maka anak akan mampu melaksanakan penyesuaian diri terhadap lingkungan sosialnya dengan baik, mandiri, tidak selalu tergantung dengan orang tua dan mudah diterima dalam anggota kelompok sosialnya, dapat mengontrol diri, mempunyai hubungan yang baik dengan teman dan kooperatif terhadap orang lain (Hurlock, 2006).

Perkembangan emosi pada anak prasekolah sangatlah penting. Perkembangan emosi anak prasekolah berpengaruh terhadap kehidupannya di masa yang akan datang. Perkembangan emosi berkaitan dengan kemampuan perasaan yang tertanam sejak awal atau dini. Emosi memainkan peran yang sedemikian penting dalam kehidupan, maka penting diketahui bagaimana perkembangan dan pengaruh emosi terhadap penyesuaian pribadi dan sosial (Hurlock, 2006). Kemampuan emosional yang dimiliki oleh anak prasekolah berhubungan dengan kemampuan anak untuk berhasil mengatasi tuntutan dan tekanan lingkungannya (Uno, 2008)

Berdasarkan data yang diperoleh peneliti di Desa Kedungupit pada tanggal 6 Oktober 2015, jumlah anak usia prasekolah sebanyak 91 anak, yaitu dengan 33 anak mempunyai riwayat paud dan 58 anak tidak mempunyai riwayat paud. Studi pendahuluan pada tanggal 30 Oktober 2015 dilakukan peneliti terhadap 9 anak didesa kedungupit, 3 dari 9 anak ketika ditanya nama tidak mau menyebutkan nama terlihat masih malu - malu, kemudian 6 dari 9 anak didapatkan mengalami masalah dalam 
kemandirian seperti masih ditunggu oleh orang tuanya, menangis saat ditinggal orang tuanya. Adapun hasil wawacara dengan beberapa orang tua mengatakan bahwa anak mengalami masalah kemandirian seperti masih memerlukan bantuan orang tua saat mengambil makanan, dalam hal makan, berpakaian dan pergi ke sekolah.

Berdasarkan latar belakang di atas, maka peneliti tertarik untuk meneliti tentang "Perbedaan Kemampuan Bersosialisasi dan kematangan emosi Pada Anak Prasekolah dengan PAUD dan tanpa PAUD di Desa Kedungupit Sragen".

\section{METODE}

Jenis penelitian ini merupakan penelitian kuantitatif dengan deskriptif komparatif yaitu penelitian untuk membandingkan keadaan suatu variable pada dua subyek yang berbeda (Arikunto, 2010). Pengukuran data menggunakan metodependekatan cross sectional (potong melintang) merupakan penelitian deskriptif dimana subjek penelitian diamati/diukur/diminta jawabannya sekaligus satu kali saja (Sugiyono, 2010). Populasi penelitian adalah anak pra sekolah di Desa Kedungupit Kabupaten Sragen yang berjumlah 91 anak, sedangkan sampel penelitian sebanyak 91 anak prasekolah dengan teknik total sampling. Pengumpulan data menggunakan kuesioner dan analisis data menggunakan uji Mann whitney t-test.

HASIL

Tabel 1. Distribusi Frekuensi Kemampuan Bersosialisasi Anak PAUD dan Non PAUD

\begin{tabular}{ccccc}
\hline Kategori & \multicolumn{2}{c}{ Non Paud } & \multicolumn{2}{c}{ Paud } \\
& Frekuensi & $\%$ & Frekuensi & $\%$ \\
\hline Kurang & 5 & 15,2 & 4 & 6,9 \\
Sedang & 24 & 72,7 & 26 & 44,8 \\
Tinggi & 4 & 12,1 & 28 & 48,3 \\
\hline Total & 33 & 100,0 & 58 & 100,0 \\
\hline
\end{tabular}

Tabel 2. Distribusi Frekuensi Kematangan Emosional Anak PAUD dan Non PAUD

\begin{tabular}{ccccc}
\hline Kategori & \multicolumn{2}{c}{ Non Paud } & \multicolumn{2}{c}{ Paud } \\
& Frekuensi & $\%$ & Frekuensi & $\%$ \\
\hline Dibawah normal & 5 & 15,2 & 0 & 0,0 \\
Normal & 28 & 84,8 & 58 & 100,00 \\
\hline Total & 33 & 100,0 & 58 & 100,0 \\
\hline
\end{tabular}

Tabel 3. Ringkasan Hasil Uji Mann Whitney Test Perbedaan Kemampuan Bersosialisasi Anak PAUD dan Non PAUD

\begin{tabular}{|c|c|c|c|c|c|c|}
\hline \multirow{2}{*}{ Kelompok } & \multicolumn{4}{|c|}{ Skor Kemampuan Bersosialisasi } & \multirow{2}{*}{$\begin{array}{l}p- \\
\text { value }\end{array}$} & \multirow{2}{*}{$\begin{array}{l}\text { Keputusan } \\
\text { uji }\end{array}$} \\
\hline & Min & Max & Mean & SD & & \\
\hline Non Paud & 6 & 16 & 13,39 & 2,56 & 0,014 & Ho ditolak \\
\hline Paud & 9 & 20 & 15,02 & 2,89 & & \\
\hline
\end{tabular}

Hasil uji Mann Whitney Test perbedaan kemampuan bersosialisasi anak prasekolah dengan Paud dan Non Paud diperoleh nilai signifikansi ( $p$-value) 0,014 lebih kecil dari 0,05 $(0,014<0,05)$ sehingga keputusan uji adalah $\mathrm{H}_{0}$ ditolak. Keputusan uji adalah $\mathrm{H}_{0}$ ditolak maka disimpulkan bahwa terdapat perbedaan kemampuan bersosialisasi anak prasekolah dengan PAUD dan Non PAUD di Desa Kedungupit Sragen. Berdasarkan nilai rata-rata (mean) skor kemampuan bersosialisasi antara kedua kelompok nampak bahwa anak prasekolah dengan Paud memiliki rata-rata lebih tinggi dibandingkan anak non Paud $(15,02>13,39)$, sehingga disimpulkan bahwa anak prasekolah yang mengikuti Paud 
memiliki kemampuan bersosialisasi lebih tinggi dibandingkan anak prasekolah non Paud.

Tabel 4. Ringkasan Hasil Uji Mann Whitney Test Perbedaan Kematangan Emosional Anak PAUD dan Non PAUD

\begin{tabular}{lllllll}
\hline Kelompok & \multicolumn{3}{l}{ Skor Kematangan Emosional } & & \multicolumn{2}{l}{$\begin{array}{l}\text { Keputusan } \\
\end{array}$} \\
& Min & Max & Mean & SD & value & uji \\
\hline Non Paud & 32 & 54 & 42,39 & 4,26 & 0,000 & Ho ditolak \\
Paud & 42 & 55 & 46,57 & 2,78 & & \\
\hline
\end{tabular}

Hasil uji Mann Whitney Test perbedaan kematangan emosional anak prasekolah dengan Paud dan Non Paud diperoleh nilai signifikansi ( $p$-value) 0,000 lebih kecil dari 0,05 $(0,000<0,05)$ sehingga keputusan uji adalah $\mathrm{H}_{0}$ ditolak. Keputusan uji adalah $\mathrm{H}_{0}$ ditolak maka disimpulkan bahwa terdapat perbedaan kematangan emosional anak prasekolah dengan PAUD dan Non PAUD di Desa Kedungupit Sragen. Berdasarkan nilai rata-rata (mean) skor kematangan emosional antara kedua kelompok nampak bahwa anak prasekolah dengan Paud memiliki rata- rata lebih tinggi dibandingkan anak non Paud $(46,57>42,39)$, sehingga disimpulkan bahwa anak prasekolah yang mengikuti Paud memiliki kematangan emosional lebih tinggi dibandingkan anak prasekolah non Paud.

\section{PEMBAHASAN}

\section{Distribusi Frekuensi Kemampuan Bersosialisasi Anak Non PAUD}

Distribusi frekuensi kemampuan bersosialisasi pada kelompok non paud menunjukkan distribusi tertinggi adalah sedang sebanyak 24 responden $(72,7 \%)$. Berdasarkan hasil penelitian menunjukkan bahwa pada kelompok non PAUD kemampuan bersosialiasi anak tergolong cukup.

Kemampuan bersosialisasi anak dipengaruhi oleh berbagai faktor yaitu faktor keluarga dan faktor di luar keluarga. Salah satu faktor keluarga yang mendukung terciptanya kemampuan bersosialisasi cukup pada responden adalah faktor pekerjaan ibu, dimana sebagian besar ibu responden merupakan ibu rumah tangga yang memiliki waktu dan kesempatan yang tinggi dalam pengasuhan anak (Hurlock, 2006).

Ibu bekerja mempunyai peran ganda selain sebagai wanita karir juga sebagai ibu rumah tangga. Salah satu dampak negatif dari ibu yang bekerja adalah tidak dapat memberikan perhatian yang penuh pada anaknya ketika anak dalam tahap tumbuh kembang yang pesat. Padahal ibu mempunyai peran penting dalam pengasuhan anak, oleh karena itu pola asuh yang tepat diperlukan agar anak dapat tumbuh kembang secara optimal. Hubungan status pekerjaan ibu dengan perkembangan anak sebagaimaan disimpulkan dalam penelitian tentang faktor-faktor yang berhubungan dengan perkembangan motorik anak usia prasekolah yang menyimpulkan ada perbedaan dalam perkembangan anak usia prasekolah antara anak dengan ibu yang bekerja dan ibu yang tidak bekerja $(p=0,047)$ (Lindawati, 2013).

Faktor lain yang mempengaruhi kemampuan bersosialisasi pada anak, yaitu pola pengasuhan orang tua, pengaruh teman sebaya, penerimaan diri, dan lingkungan (Hurlock dalam Joko, 2009). Usia prasekolah memberi kesempatan luas kepada anak untuk mengembangkan keterampilan sosialnya. Di usia inilah anak mulai melihat dunia lain di luar dunia rumah bersama ayah dan ibu. Kemampuan bersosialisasi harus terus diasah, selanjutnya keberhasilan bersosialisasi anak berhubungan dengan banyaknya relasi yang sudah dijalin (Isye, 2006).

Anak usia prasekolah umumnya merupakan kelompok anak yang suka dengan bermain baik secara individual maupun secara berkelompok. Budaya masyarakat di Desa Kedungupit Sragen tentang pola bermain anak-anak umumnya masih seperti anak-anak di Desa lainnya di Jawa, yaitu bermain bersama-sama dengan teman. Hubungan yang terjadi antara anak prasekolah ketika bermain anak berinteraksi dengan teman-temannya sehingga memberikan kesempatan kepada anak untuk mengembangkan kemampuan bersosialisasinya (Dini, 2011). 


\section{Distribusi Frekuensi Kemampuan Bersosialisasi Anak PAUD}

Distribusi frekuensi kemampuan bersosialisasi pada kelompok paud menunjukkan tinggi sebanyak 28 responden $(48,3 \%)$. Berdasarkan hasil penelitian menunjukkan bahwa pada kelompok PAUD kemampuan bersosialiasi anak tergolong tinggi.

Salah satu tujuan pendidikan anak usia dini (PAUD) adalah untuk membantu anak tumbuh dan berkembang sesuai dengan tingkat perkembangannya, sehingga mereka memiliki kesiapan yang optimal dalam memasuki pendidikan dasar serta mengaruhi kehidupan di masa yang akan datang (Santi (2009). Selanjutnya prinsip- prinsip pendidikan anak usia dini adalah dengan mendidikan yang berorientasikan kepada perkembangan anak didik, sehingga cara pengasuhan dan pendidikan anak di PAUD dilakukan secara bertahap, sederhana ke rumit, dari kongkrit ke abstrak, dan dari gerakan verbal ke akuran dan ke rasa (Suyadi, 2014). Tujuan dan prinsip pembelajaran anak pra sekolah selama mengikuti program PAUD membantu anak mengembangkan potensi dirinya termasuk kemampuan bersosialisasi anak.

\section{Distribusi Frekuensi Kematangan Emosional Anak Non PAUD}

Distribusi frekuensi kematangan emosional pada kelompon non paud menunjukkan distribusi tertinggi adalah normal sebanyak 28 responden (84,8\%). Perkembangan emosi berkaitan dengan kemampuan perasaan yang tertanam sejak awal atau dini. Emosi memainkan peran yang sedemikian penting dalam kehidupan, maka penting diketahui bagaimana perkembangan dan pengaruh emosi terhadap penyesuaian pribadi dan sosial (Hurlock, 2006).

Pada masa awal kanak-kanak emosi sangat kuat. Saat ini merupakan saat ketidak seimbangan karena anak-anak keluar dari fokus, dalam arti bahwa ia mudah terbawa ledakan-ledakan emosional sehingga sulit dibimbing dan diarahkan. Emosi yang tinggi kebanyakan disebabkan oleh masalah psikologis daripada masalah fisiologis. Orang tua hanya memperbolehkan anak melakukan beberapa hal, padahal anak merasa mampu melakukan lebih banyak lagi dan ia cenderung menolak larangan orang tua (Muscari, 2007).

Salah satu faktor yang berhubungan dengan kematangan emosional anak adalah faktor keluarga. Status pekerjaan ibu menunjukkan bahwa sebagian besar ibu adalah ibu rumah tangga yang secara waktu memiliki waktu lebih banyak dalam pengasuhan anak. Keluarga merupakan lingkungan pertama dan utama bagi perkembangan sosial emosional anak. Keluarga adalah lembaga pertumbuhan dan belajar awal yang dapat menghantarkan anak menuju pertumbuhan dan belajar selanjutnya. Pola pengasuhan yang diperoleh anak dari keluarganya akan sangat berpengaruh terhadap perkembangan sosial emosional anak, misalnya pola pengasuhan tidak peduli membuat anak implusif. Keberadaan ibu di rumah menyebabkan perhatian ibu terhadap anak menjadi lebih baik dan berdampak pada terciptakan perkembangan emosional yang baik pada anak (Nugraha, 2008).

\section{Distribusi Frekuensi Kematangan Emosional Anak Prasekolah dengan PAUD}

Distribusi frekuensi kematangan emosional pada kelompok paud semua responden memiliki kematangan emosional dalam kategori normal. Pertumbuhan dan perkembangan manusia merupakan sesuatu yang dapat diprediksi. Proses tersebut terjadi pada manusia dan bersifat individual. Kesuksesan atau kegagalan individu dalam menyelesaikan fase-fase berikutnya (Potter \& Perry, 2005). Fase prasekolah merupakan salah satu tahap perkembangan pada anak usia usia tiga sampai enam tahun. Tahap perkembangan kognitif, bahasa, fisik (motorik kasar dan halus), dan psikososial. Pada tahap ini perkembangan anak dipengaruhi berbagai factor selain keluarga juga factor intervensi pendidikan yang diterima oleh anak (Wong, 2009).

Anak-anak yang mendapatkan pendidikan PAUD akan menerima stimulus berupa pelatihanpelatihan dan pendidikan dengan metode-metode yang sesuai dengan kemampuan anak. Johan (2006) mengemukakan bahwa anak yang menerima pendidikan PAUD akan memperoleh stimulus melalui PAUD, sehingga anak tidak mengalami keterlambatan dalam perkembangan psikososialnya. 


\section{Perbedaan Kemampuan Bersosialisasi antara Anak Non Paud dan Paud}

Hasil uji Mann Whitney Test perbedaan kemampuan bersosialisasi anak prasekolah dengan Paud dan Non Paud diperoleh nilai signifikansi ( $p$-value) 0,014 sehingga disimpulkan bahwa terdapat perbedaan kemampuan bersosialisasi anak prasekolah dengan PAUD dan Non PAUD di Desa Kedungupit Sragen. Berdasarkan nilai rata- rata (mean) skor kemampuan bersosialisasi antara kedua kelompok nampak bahwa anak prasekolah dengan Paud memiliki rata-rata lebih tinggi dibandingkan anak non Paud $(15,02>13,39)$, sehingga disimpulkan bahwa anak prasekolah yang mengikuti Paud memiliki kemampuan bersosialisasi lebih tinggi dibandingkan anak prasekolah non Paud.

Faktor-faktor yang berhubungan dengan perkembangan emosional anak prasekolah antara lain peran kematangan dan peran belajar. Masa kanak-kanak awal sering disebut "usia pragang" (pregang age). Pada masa ini sejumlah hubungan yang dilakukan anak dengan anak-anak lain meningkat dan ini sebagian menentukan bagaimana gerak maju perkembangan sosial mereka. Anak-anak yang mengikuti pendidikan prasekolah, misalnya pendidikan untuk anak sebelum taman kanak-kanak (nursery school), pusat pengasuhan anak pada siang hari (day care center), atau taman kanak-kanak (kingdergarden), biasanya mempunyai sejumlah besar hubungan sosial yang telah ditentukan dengan anak-anak yang umur sebaya. Anak yang mengikuti pendidikan prasekolah melakukan penyesuaian sosial yang lebih baik dibandingkan dengan anak-anak yang tidak mengikuti pendidikan prasekolah. Anak pra sekolah yang mengikuti pendidikan prasekolah dipersiapkan secara lebih baik untuk melakukan partisipasi yang aktif dalam kelompok disanding dengan anak-anak yang aktivitas sosialnya terbatas dengan anggota keluarga dan anak-anak lingkungan tetangga terdekat (dalam Fikriyati 2013 : 103-104).

Ingrid \& Yoshie (2009) mengemukakan bahwa ada konsensus para ahli menyebutkan bahwa upaya peningkatan perkembangan anak secara berkelanjutan dimulai dari pendidikan usia dini. Pendidikan pada usia dini bertujuan untuk memberikan fondasi tentang intelektual, psikologis, emosional, social dan fisik yang sehat pada anak. Pemberian pondasi yang kuat tersebut akan berdampak pada berkelanjutannya perkembangan anak baik secara fisik maupun emosional.

Penelitian menunjukkan terdapat perbedaan kemampuan bersosialisasi antara anak Paud dan Non Paud dimana anak prasekolah yang mengikuti Paud memiliki kemampuan bersosialisasi lebih tinggi dibandingkan anak prasekolah non Paud. Hasil penelitian ini didukung oleh penelitian terdahulu yaitu penelitian Ni Putu (2015) tentang hubungan latar belakang pendidikan play group dengan perkembangan psikososial anak yang menyimpulkan bahwa ada hubungan antara latar belakang pendidikan playgroup dengan perkembangan psikososial anak di TK Bhayangkari Gianyar.

Hasil penelitian tersebut berbeda dengan penelitian Trinataliswati (2010) tentang berbedaan kemampuan bersosialisasi pada anak prasekolah dengan riwayat Paud dan tanpa riwayat Paud di Desa Sumber Porong Lawang. Penelitian ini menunjukkan tidak ada perbedaan kemampuan bersosialisasi pada anak prasekolah dengan riwayat Paud dan tanpa riwayat Paud. Tidak adanya perbedaan hal ini dapat disebabkan karena walaupun anak tidak pernah memasuki lingkungan sekolah (kelompok bermain) tetapi karena lingkungan keluarga, saudara dan teman sangat mendukung dan sudah memberikan peluang terhadap perkembangan sosial anak secara positif maka anak mampu mencapai kernatangan dalam bersosialisasi.

Penelitian (Trinataliswati, 2010) menunjukkan bahwa ada faktor lain yang mempengaruhi kemampuan bersosialisasi anak prasekolah dengan riwayat PAUD (kelompok bermain) dan tanpa riwayat PAUD. Faktor-faktor tersebut adalah faktor dari dalam diri anak yang meliputi kepribadian, intelegensi, bakat dan minat, karena dalam perkembangannya anak akan mengalami perubahan yang terus-menerus seperti memupuk keberanian untuk lebih mengenal lingkungannya dan mengembangkan kreativitasnya dan semua itu tidak terlepas dari dunia bermain anak, karena semakin banyak aktifitas bermain dilakukan dan semakin sering atau dalam waktu yang lama anak saling berinteraksi dengan teman-temannya akan semakin membuat kondisi mental lebih baik dan itu akan mendukung pencapaian kematangan kemampuan bersosialisasi. Walaupun demikian bukan berarti pendidikan anak usia dini khususnya yang non formal seperti kelompok bermain tidak begitu penting 
sehingga orang tua tidak perlu berfikir untuk merencanakan memasukkan anak anaknya ke dalam lembaga tersebut karena meskipun peranan orang tua atau keluarga sangat memegang peranan penting tetapi kematangan penyesuaian sosial anak akan sangat terbantu apabila anak dimasukkan ke kelompok bermain atau sekolah sekolah non formal lainnya sebab tempat tersebut dapat menjadi sarana untuk berinteraksi dengan teman sebaya merupakan tempat yang memberikan peluang kepada anak untuk belajar memperluas pergaulan sosialnya (Trinataliswati, 2010).

\section{Perbedaan Kematangan Emosional antara Anak Non Paud dan Paud}

Hasil uji Mann Whitney Test perbedaan kematangan emosional anak prasekolah dengan Paud dan Non Paud diperoleh nilai signifikansi ( $p$-value) 0,000 sehingga disimpulkan terdapat perbedaan kematangan emosional anak prasekolah dengan PAUD dan Non PAUD di Desa Kedungupit Sragen, yaitu anak prasekolah yang mengikuti Paud memiliki kematangan emosional lebih tinggi dibandingkan anak prasekolah non Paud.

Perkembangan emosi berkaitan dengan kemampuan perasaan yang tertanam sejak awal atau dini. Emosi memainkan peran yang sedemikian penting dalam kehidupan, maka penting diketahui bagaimana perkembangan dan pengaruh emosi terhadap penyesuaian pribadi dan sosial (Hurlock, 2006).

Pada masa awal kanak-kanak emosi sangat kuat. Saat inimerupakan saat ketidak seimbangan karena anak-anak keluar dari fokus, dalam arti bahwa ia mudah terbawa ledakan-ledakan emosional sehingga sulit dibimbing dan diarahkan. Emosi yang tinggi kebanyakan disebabkan oleh masalah psikologis daripada masalah fisiologis. Orang tua hanya memperbolehkan anak melakukan beberapa hal, padahal anak merasa mampu melakukan lebih banyaklagi dan ia cenderung menolak larangan orang tua (Muscari, 2007).

Penelitian ini menunjukkan bahwa terdapat perbedaan kematangan emosional antara anak pra sekolah dengan riwayat Paud dan non Paud, dimana anak prasekolah dengan riwayat Paud memiliki kematangan emosional lebih baik dibandingkan anak prasekolah non paud. Hasil penelitian ini didukung oleh penelitian Achmad (2013) tentang perkembangan psikososial pada anak prasekolah yang mengikuti dan tidak mengikuti Paud. Penelitian ini menyimpulkan bahwa hubungan yang bermakna antara keikutsertaan anak dalam Paud dengan perkembangan psikososial anak prasekolah.

Hasil penelitian ini tidak didukung oleh penelitian Siswoyo (2012) tentang perbedaan tingkat perkembangan personal social pada anak usai prasekolah yang menjalani Paud dan tidak Paud. Penelitian ini menyimpulkan tidak terdapat perbedaan perkembangan personal social pada anak usia prasekolah yang menjalani Paud dan Non Paud. Penelitian tersebut menyebutkan bahwa terdapat faktor lain yang lebih dominant mempengaruhi perkembangan personal social anak prasekolah yaitu keterlibatan orang tua dalam perkembangan anak.

\section{KESIMPULAN}

Kemampuan bersosialisasi pada anak dengan riwayat PAUD di Desa Kedungupit Sragen sebagian besar adalah tinggi sedangkan pada anak non Paud sebagian besar adalah sedang. Kematangan emosional pada anak dengan riwayat PAUD dan tanpa PAUD di Desa Kedungupit Sragen sebagian besar adalah normal. Terdapat perbedaan kemampuan bersosialisasi pada anak prasekolah dengan PAUD dan tanpa PAUD di Desa Kedungupit Sragen. Terdapat perbedaan kematangan emosional pada anak prasekolah dengan PAUD dan tanpa PAUD di Desa Kedungupit Sragen.

Orang tua anak prasekolah hendaknya mengikutsertakan anaknya dalam pendidikan anak usia dini (PAUD) agar anak mendapatkan bekal sebelum memasuki bangku sekolah. Sedangkan bagi orang tua yang tidak memasukkan anaknya ke Paud hendaknya memberikan dukungan dan bimbingan yang kuat kepada anak, misalnya dengan melatih anak untuk dapat bersosialisasi dan beradaptasi dengan orang lain sehbingga anak memiliki kesiapan ketika memasuki bangku sekolah. Institusi kesehatan hendaknya memberikan bekal pengetahuan yang cukup kepada mahasiswanya khususnya tentang perkembangan anak praskolah, sehingga mahasiswa mampu menjadi nara sumber bagi masyarakat 
tentang perkembangan anak prasekolah. Peneliti selanjutnya yang ingin meneliti dengan tema sejenis hendaknya menambah faktor-faktor lain yang berhubungan dengan kemampuan bersosialiasi dan kematangan emosional anak prasekolah misalnya faktor keluarga, faktor lingkungan, umur anak, dan kondisi fisik anak. Peneliti selanjutnya hendaknya dalam melakukan observasi dapat memposisikan dirinya agar responden merasa nyaman sehingga mereka melakukan aktivitas kesehariannya sebagaimana perilakunya sehari-hari.

\section{DAFTAR PUSTAKA}

Achmad, D. (2013). Perkembangan Psikososial Pada Anak Prasekolah Yang Mengikuti Dan Tidak Mengikuti PAUD. Jurnal Kesehatan. Jakarta: FKUI.

Desmita. (2007). Psikologi Perkembangan. Bandung: PT Rosda Karya

Dini, W (2011). Kemampuan Sosial Emosional Anak Kelompok A di TK Nurul Ulum Bambe Driyorejo Gresik. Jurnal Pendidikan. Surabaya: Fakultas Ilmu Pendidikan Universitas Negeri Surabaya.

Djamarah, SB. (2011). Psikologi Belajar. Jakarta: PT Rineka Cipta.

Euis S, Lusiaana, T, dan Florence. (2004). Pengembangan Alat Ukur Kecerdasan Emosional Remaja. Jurnal Penelitian. Bogor: Jurusan Gizi Masyarakat dan Sumber Daya Keluarga. Fakultas Pertanian, IPB.

Eun, Y.L. (2006). Measuring Social Compentence in Preschool-Aged Children Through the Examination of Play Behaviors. Theses and Dissertation Publication. USA: University of South Florida.

Fahman, Morrel, Stuart, and John. (2008) Behavioural, Social, and Emotional Assessment of Children and Adolesent. New York: Routledge Taylor and Francis Group.

Fikriyati. (2013). Karakteristik Perkembangan Anak Usia Dini. Jurnal Lentera Pendidikan. 12, 1.

Hurlock, E. B. (2008). Perkembangan Anak. Jilid I, Edisi 6. Jakarta: Erlangga.

Ibung, (2009). Mengembangkan Nilai Moral pada Anak. Jakarta : PT Media Elex Komputindo. http://books.google.co.id/books.

Isye, W, (2006), Sampai di Dana Kemampuan Anak Prasekolah?, Jakarta: Klinik Pela.

Joko, S. (2009). Hubungan Pola Asuh Orang Tua terhadap Kemampuan Sosialisasi pada Anak Prasekolah di TK Pertiwi Purwokerto Utara. Jurnal Keperawatan Soedirman. Volume 4, No. 3, November 2009.

Komariah, Nurul. (2012). Analisis Kemampuan Sosialisasi Anak Prasekolah. Jurnal Kebidanan. Poltekkes Kemenkes Palembang Jurusan Kebidanan.

Lindawati (2013). Faktor-faktor yang Berhubungan dengan Perkembangan Motorik Anak Usia Prasekolah. Jurnal Healthy Quality Vol. 4 No. 1, November 2013.

Mansur. (2007). Pendidikan Anak Usia Dini dalam Islam. Yogyakarta: Pustaka Pelajar.

Muscari, M. E. (2005). Panduan Belajar Keperawatan Pediatrik Edisi 3. Jakarta: EGC.

Ni Putu, SA. (2015). Hubungan Latar Belakang Pendidikan Play Group dengan Perkembangan Psikososial Anak. KMB Maternitas Anak dan Kritis. Juli Volume 2 No. 12015.

Papalia, Olds, \& Feldman, (2009). Human Development (Psikologi Perkembangan). Jakarta: Kencana.

Patmonodewo, S. (2008). Pendidikan Anak Pasekolah. Jakarta : Renika Cipta

Potter dan Perry (2005). Fundamental Nursing: Concept, Process and Practice. Sixth Edition. St. Louis. Mosby New York.

Pusat Kurikulum Departemen Pendidikan Nasional (2007). Kajian Standar Isi Pendidikan Dasar dan PAUD. Jakarta: Departemen Pendidikan Nasional.

Riyanto, Theo. (2004). Pembelajaran Sebagi Proses Bimbingan Pribadi. Jakarta: Gramedia Widiasarana Indonesia.

Salimar. (2011). Hubungan Beban Kerja, Pengetahuan Ibu, Pola Asuh Psikososial Dengan Perkembangan Kognitif Anak Usia 2-5 tahun. PGM 2011. IPB: Departemen Ilmu Keluarga dan Perkembngan Anak.

Santi, D. (2009). Pendidikan Anak Usia Dini. Jakarta : indeks.

Setiawan, (2010). Masalah Sosial Anak Meningkat. Pikiran Rakyat (on line). Tersedia : http//bataviase.co.id. 
Siswoyo. (2011) Perbedaan Tingkat Perkembangan Personal Social Pada Anak Usai Prasekolah Yang Menjalani PAUD dan Tidak PAUD. J. Indon Med Assoe, Volume 61, September 2011.

Slameto. (2013). Belajar dan Faktor-Faktor yang Mempengaruhinya. Jakarta: PT. Rineka Cipta.

Soetjiningsih G. (2014). Tumbuh Kembang Anak. Jakarta: EGC.

Sulistyawati, Ari. (2014). Deteksi Tumbuh Kembang Anak. Jakarta : Salemba Medika. Susanto, A. (2011). Perkembangan Anak Usia Dini. Jakarta: Kencana

Suyadi. (2014). Teori pembelajaran anak usia dini. Bandung : Remaja Rosdakarya.

Trinataliswati. (2010). Berbedaan Kemampuan Bersosialisasi Pada Anak Prasekolah Dengan Riwayat Paud Dan Tanpa Riwayat PAUD di Desa Sumber Porong Lawang. Jurnal Keperawatan. Volume 1 No. 2. ISSN : 2086-3071

Ulfa, A. K. (2011). Peran Orang Tua dalam Perkembangan Emosi Anak TK Tarbiyatul Athfal di Bakalan Susukan Semarang. Jurnal Penelitian. Surakarta: Progdi Pendidikan Anak Usia Dini, FKIP, Universitas Muhammadiyah Surakarta.

Uno, H.B., (2008), Orientasi Baru dalam Psikologi Pembelajaran, Penerbit Bumi Aksara, Jakata.

Wong, DL. (2009). Buku Ajar Keperatawan Pediatrik. Edisi 6. Volume 2. Jakarta: EGC.

Yamin M dan Sanan JS. (2013). Panduan PAUD. Pendidikan Anak Usia Dini. Jakarta: Gaung Persada Press Group.

Yusuf, (2011). Psikologi Perkembangan Anak dan Remaja. Bandung : Remaja Rosdakarya. 